\title{
SURVEY OF TRUE SPIDERS IN THE EGYPTIAN RIEC FIELDS AT RASHEID REGION BEHEIRA GAVARNARTE Shawer, M.B. ${ }^{*}$; F. A. Sharshir ${ }^{*}$; A.S. Hendawy ${ }^{*}$ and E. A. Refaei ${ }^{\star}$ Fac. Agric., Kafrelsheikh Univ., Egypt \\ ** Plant Prot. Res. Inst., Sakha Agric. Res. Sta., ARC, Egypt
}

\begin{abstract}
A survey was carried out at farms of Rasheid, Beheira gavernorate during two successive rice seasons, 2009 and 2010. Two sowing dates were studied; the first is the normal date of sowing (early May), the second sowing date is the late one (early June) using three traps (sweep net,pit fall and water pan). 10 species of true spiders were belonging to 6 families surveyed from the Egyptian rice fields. The spiders were recorded for the first date 9 species of true spiders were surveyed from rice fields at from Rasheid EL- Behira governorate. 6 spider families were surveyed, with 807 individuals belonging to 9 spider Species. The surveyed spiders and Families and their percentages were as follows: Thomicidae (Thomisius $\mathrm{sp}$ ) with $3.46 \%$ Lycosidae (Lycosa sp., Pardosa spp., Trochosa sp.,) with $9.04 \% 25.65 \%$ and $7.89 \%$, respectively. Tetragnothridae had two species (Tetragnatha javana, Tetragnatha nitens) with $40.89 \%$. Philodromidae (Thanatus Albini)) with $4.08 \%$ Araneidae (Singa sp.) with $6.44 \%$ and Pisawridae (Dolomedes sp.) with2. $72 \%$ and the second 7 spider families were surveyed, with 719 individuals belonging to 10 spider Species. The surveyed spared and Families and their percentages were as follows: Thomicidae (Thomisius sp.) with2.78\% Lycosidae (Lycosa sp., Pardosa spp., Trochosa sp.,) with $9.59 \% 17.52$ $\%$ and $3.47 \%$, respectively. Tetragnothridae had if two species (Tetragnatha javana, Tetragnatha nitens) with $54.65 \%$ Philodromidae (Thanatus Albini)) with $3.33 \%$ Araneidae (Singa sp.) with $5.98 \%$ and Pisawridae (Dolomedes sp.) with $2.50 \%$ and Salticidae Mendoza sp with $0.13 \%$.
\end{abstract}

\section{INTRODUCTION}

Spiders in agroecosystems play an important role in pest suppression and contribute to biodiversity. Spiders appear in different ecosystems in a wide assemblage. Numerous researchers have stressed that an assemblage of spider species is more effective at reducing prey densities than a single species of spider (Greenstone, 1999 and Sunderland, 1999).

Spiders (order Araneae) are air-breathing arthropods that have eight legs and chelicerae with fangs that inject venom. They are the largest order of arachnids and rank seventh in total species diversity among all other groups of organisms.

They are capable of reducing populations of herbivores that may not be limited by competition and food availability in some agroecosystems (Sunderland, 1999). Spiders can lower insect densities, as well as stabilize populations by virtue of their top-down effects, microhabitat use, prey selection polyphagy, functional responses, numerical responses, and obligate predatory feeding. As biological control agents, spiders must be present in crop fields and prey upon specific agricultural pests (Francis and Randy 2003) 
Spiders are found worldwide on every continent except for Antarctica, and have become established in nearly every habitat with the exception of air and sea colonization. As of 2008, approximately 40,000 spider species, and 109 families have been recorded by taxonomists.

Spiders are common predators prevailing in rice fields in Egypt. These predatory animals are important in reducing rice insects, and as such are of potential value in biological control (Young and Edward 1990 and Wise 1993). Since the predatory complex reduces insect herbivore populations, which in turn reduces damage to crop plants (van den Bosch et al., 1982), it is important to conserve these natural enemies, and add new species to ecosystems if possible. It was reported by several studies that assemblages of many predatory species may be more effective at controlling agricultural pests than single species augmentation (Chiverton 1986; Clark et al., 1994; Riechert and Lawrence 1997). Identified specimens of Egyptian fauna revealed the occurrence of eleven spider species belonging to six families (Sherif et al., 2001).

The present investigation amied to:

1- $\quad$ survey of true spiders by different kinds of traps .

2- Monitor population fluctuations of true spider Tetragnatha spp and leafhopper in rice fields.

\section{MATERIALS AND METHODS}

\section{Survey of true spider species in rice fields}

The Spiders were collected from three rice nurseries $\left(200 \mathrm{~m}^{2}\right.$ each), and from the permanent rice field (1/2 fed). In the nursery. sweep net, pit fall, water pan and fine screen traps were used at a rate of one trap / nursery. In the permanent field, ten traps of pitfall and water pan were used as well as 50 double strokes by the sweep net conducted twice a week in the nurseries, and weekly in the permanent field. Sampling covered the period extending farm early May up to early October. Two rice sowing dates were studied; the first is the normal date of sowing (early May), the second is the late (sown an early June after harvesting of seed watermelon).

Samples were preserved in $70 \%$ ethyl alcohol until identification. Spiders classification was achieved at Plant Protection Research Institute, Agricultural Research Center, Ministry of Agriculture, Egypt through Prof Dr. A. S. Hendawey .

\section{Population Fluctuatios, of True spider Species:}

Population fluctuations of the most common species, the true spider Tetragnatha spp and Leafhopper, belonging to order Homoptera, were monitored using the sweep net. Fifty double strokes were practiced weekly from May till the beginning of October. Two sowing dates were studied; the first is the normal date of sowing (early May), the second sowing date is the late (sown after harvesting of seed watermelon). 


\section{RESULTS AND DISCUSSION}

\section{Survey of True Spider Species in Rice fields}

Nine species of true spiders were surveyed from rice fields at two cultivations from Rasheid region EL- Behira governorate.

\section{The First date .}

Data in Table (1) show that nine spider species (807 individuals) belonging to 6 spider families were surveyed. The surveyed spiders and families and their percentages were as follows: Thomicidae (Thomisius sp.) with 3.46\%, Lycosidae (Lycosa sp., Pardosa spp., Trochosa sp.) with $9.04 \%$ $25.65 \%$ and $7.68 \%$, respectively. Tetragnathridae had two species (Tetragnatha javana, Tetragnatha nitens) with $40.89 \%$, Philodromidae (Thanatus albini)) with $4.08 \%$, Araneidae (Singa sp.) with $6.44 \%$ and Pisauridae (Dolomedes sp.) with 2. $72 \%$. Assas and Boraei (2005) recorded 23 species of spiders in the rice fields at kafr El- sheikh region.

Table(1):Spider species and numbers, collected from Rasheid region, EL- Behira Governorate from the first cultivation during 2009and 2010 seasons.

\begin{tabular}{|c|c|c|c|c|c|c|}
\hline Family & Spider species & Sweep net & Water pan & Pit- fall & Total & $\%$ \\
\hline Thomicidae & Thomisius sp. & 28 & 0 & 0 & 28 & 3.46 \\
\hline \multirow{3}{*}{ Lycosidae } & Lycosa sp & 33 & 23 & 17 & 73 & 9.04 \\
\hline & Pardosa spp & 90 & 44 & 73 & 207 & 25.65 \\
\hline & Trochosa sp & 0 & 62 & 0 & 62 & 7.68 \\
\hline Tetragnothridae & $\begin{array}{l}\text { Tetragnatha javana } \\
\text { Tetragnatha nitens }\end{array}$ & 271 & 59 & 0 & 330 & 40.89 \\
\hline Philodromidae & Thanatus Albini & 33 & 0 & 0 & 33 & 4.08 \\
\hline Araneidae & Singa sp. & 52 & 0 & 0 & 52 & 6.44 \\
\hline Pisauridae & Dolomedes sp & 22 & 0 & 0 & 22 & 2.72 \\
\hline Total & & 529 & 188 & 90 & 807 & 100 \\
\hline
\end{tabular}

The sacond date .

Data in Table (2) show that ten spider species (719 individuals)belonging to seven spider families were surveyed. The surveyed species and families and their percentages were as follows: Thomicidae (Thomisius sp.) with $2.78 \%$ Lycosidae (Lycosa sp., Pardosa spp., Trochosa sp.,) with $9.59 \% 17.52 \%$ and $3.47 \%$, respectively. Tetragnothridae had two species (Tetragnatha javana, Tetragnatha nitens) with $54.65 \%$ Philodromidae (Thanatus albini)) with $3.33 \%$, Araneidae (Singa sp.) with $5.98 \%$ and Pisawridae (Dolomedes sp.) with $2.50 \%$ and Salticidae Mendoza sp with $0.13 \%$

Assas and Boraei (2005) recorded 23 species of spiders in the rice fields at Kafr El- sheikh. It is obvious , from Table (1 \& 2) that Tetragnathidae spiders were the must dominant . 
Table(2): Spider species and numbers, collected from Rasheid region EL- Behira Governorate from the saconed cultivation during 2009and 2010 seasons.

\begin{tabular}{|l|l|c|c|c|c|c|}
\hline \multicolumn{1}{|c|}{ Family } & \multicolumn{1}{|c|}{ Spider species } & Sweep net & $\begin{array}{c}\text { Water } \\
\text { pan }\end{array}$ & $\begin{array}{c}\text { Pit- } \\
\text { fall }\end{array}$ & Total & $\%$ \\
\hline Thomicidae & Thomisius sp. & 20 & 0 & 0 & 20 & 2.78 \\
\hline \multirow{3}{*}{ Lycosidae } & Lycosa sp & 36 & 20 & 13 & 69 & 9.59 \\
\cline { 2 - 8 } & Pardosa spp & 70 & 25 & 31 & 126 & 17.52 \\
\cline { 2 - 8 } & Trochosa sp & 0 & 0 & 25 & 25 & 3.47 \\
\hline Tetragnothridae & Tetragnatha javana & 341 & 52 & 0 & 393 & 54.65 \\
\hline Philodromidae & Tetragnatha nitens & & & & & \\
\hline Araneidae & Thanatus Albini & 24 & 0 & 0 & 24 & 3.33 \\
\hline Pisauridae & Singa sp. & 43 & 0 & 0 & 43 & 5.98 \\
\hline Salticidae & Dolomedes sp & 18 & 0 & 0 & 18 & 2.50 \\
\hline Total & Mendoza sp. & 1 & 0 & 0 & 1 & 0.13 \\
\hline
\end{tabular}

2- Population Fluctuations of True spider Tetragnatha spp and leafhopper, in rice fields.

The First date.

Data in Table (3) and Fig (1) show the population fluctuations of Tetragnatha spp belonging to family Tetragnathaidae and Leafhopper, belonging to order Homoptera durig two sowing dates of rice fields in 2009 and 2010. Nentwig (1987) reported that small pests, such as thrips, midges and aphids, may die by being caught in the webs of large spiders even when they are ignored by the spider. In 2009 season, Tetragnatha spp were not detected in rice nurseries. In permanent field, the spider exhibited four peaks: on 11 July (13 individuals /50 double stroks ), 1 August (26 individuals),22 August (22 individuals) and on 5 September (15 individuals). Leafhopper, was encountered in one peak in the nursery ; on 6 June $(9$ individuals $/ 50$ double stroks ), and 3 peaks in the permanent field ; on 27 Jun. (15 individuals), 1 August (18 individuals), and on 5 September (11 individuals).

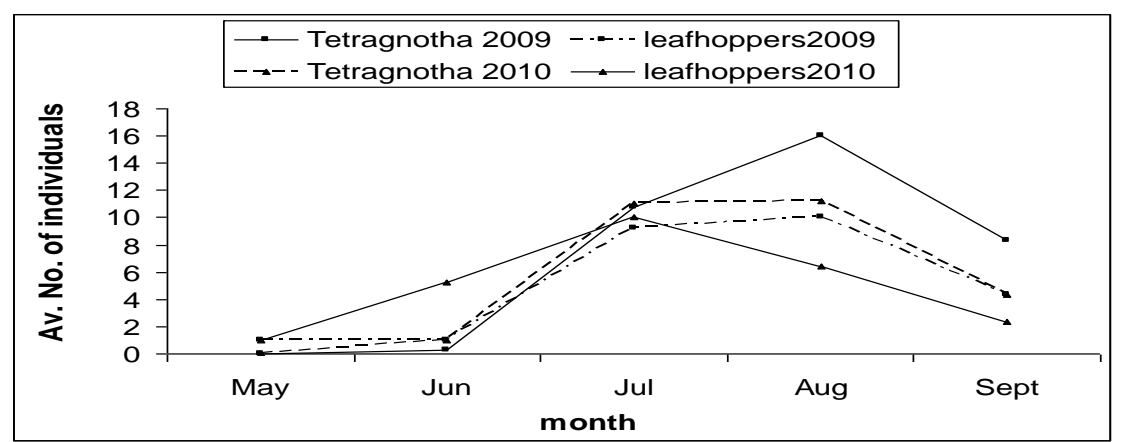

Fig (1): Population fluctuations of family Tetragnotha spp and rice leafhopper, per/ $\mathbf{5 0}$ double strokes in rice fields in first date.

In 2010 season, Tetragnatha spp were not detected in rice nurseries. The permanent field, the spider exhibited four peaks; on 18 July (19 
individuals /50 double stroks ), 1 August (14 individuals),29 August (24 individuals) and on 5 September (10 individuals). Leafhopper, was encountered in one peak in the nursery; on 8 Jun. (12 individuals /50 double stroks ), and 3 peaks in In permanent field ; on 4 Jul. (16 individuals), 8 August (11 individuals), and on 5 September (7 individuals).

Table (3):Population fluctuations of family Tetragnotha spp and rice leafhopper, per/ 50 double strokes in rice fields.

\begin{tabular}{|c|c|c|c|c|}
\hline Date of collection & \multicolumn{2}{|c|}{2009} & \multicolumn{2}{|c|}{2010} \\
\hline \multicolumn{3}{|c|}{ First date } & & \\
\hline Nursery & Tetragnothaa & Leafhopper & Tetragnothaa & Leafhopper \\
\hline May 23 & 0 & 0 & 0 & 2 \\
\hline 25 & 0 & 3 & 0 & 5 \\
\hline 27 & 0 & 0 & 0 & 3 \\
\hline 29 & 0 & 2 & 0 & 2 \\
\hline 31 & 0 & 0 & 0 & 6 \\
\hline Jun2 & 0 & 5 & 0 & 3 \\
\hline 4 & 0 & 0 & 0 & 6 \\
\hline 6 & 0 & 9 & 0 & 3 \\
\hline 8 & 0 & 3 & 0 & 12 \\
\hline 10 & 0 & 6 & 0 & 3 \\
\hline 12 & 0 & 4 & 0 & 7 \\
\hline \multicolumn{5}{|l|}{ Rice field } \\
\hline Jun 20 & 0 & 0 & 2 & 3 \\
\hline & 2 & 15 & 6 & 5 \\
\hline Jul.4 & 10 & 12 & 14 & 16 \\
\hline 11 & 13 & 6 & 5 & 13 \\
\hline 18 & 8 & 11 & 19 & 5 \\
\hline 25 & 12 & 8 & 6 & 6 \\
\hline Aug. 1 & 26 & 18 & 14 & 3 \\
\hline 8 & 14 & 13 & 10 & 11 \\
\hline 15 & 12 & 5 & 5 & 5 \\
\hline 22 & 22 & 6 & 3 & 8 \\
\hline 29 & 6 & 8 & 24 & 5 \\
\hline Sept. 5 & 15 & 11 & 10 & 7 \\
\hline 12 & 10 & 2 & 3 & 0 \\
\hline 19 & 0 & 0 & 0 & 0 \\
\hline Total & 150 & 147 & 121 & 139 \\
\hline
\end{tabular}

The sacond date

Data in Table (4) and Fig (2) show the population fluctuations of Tetragnatha spp belonging to family Tetragnathaidae and Leafhopper, belonging to order Homoptera durig two sowing dates of rice fields in 2009 and 2010. Nentwig (1987) reported that small pests, such as thrips, midges and aphids, may die by being caught in the webs of large spiders even when they are ignored by the spider. In2009 season, Tetragnatha spp were not detected in rice nurseries. In permanent field, the spider exhibited four peaks; an 29 August (12 individuals $/ 50$ double stroks ),12 September (30 individuals),26 September (27 individuals) and on 1 Oct.(10 individuals). Leafhopper, was encountered in 2 peak in the nursery ; an 6 Jul (13 individuals $/ 50$ double stroks ), on 18 Jul. (19 individuals), and 3 peaks in the permanent field ; on 22 August. (14 individuals), 5 September (30 individuals), and on 19 September 22 individuals). In 2010 season, Tetragnatha spp were not 
detected in rice nurseries. The permanent field, the spider exhibited four peaks; on 29 August ( 27 individuals /50 double stroks ), 5 September (37 individuals),26 September (41 individuals) and on 1 Oct. (23 individuals). Leafhopper, was encountered in one peak in the nursery ; on 5 . (25 individuals $/ 50$ double stroks ), and 3 peaks in the permanent field ; on 8 August. (22 individuals), 5 September (12 individuals), and on 1 Oct.(5 individuals).

Table (4): Population fluctuations of family Tetragnotha spp and rice Leafhopper, per/ 50 double strokes in rice fields

\begin{tabular}{|c|c|c|c|c|}
\hline Date of collection & \multicolumn{2}{|c|}{2009} & \multicolumn{2}{|c|}{2010} \\
\hline \multicolumn{5}{|c|}{ Saconed date } \\
\hline Nursery & Tetragnothaa & Leafhopper & Tetragnothaa & Leafhopper \\
\hline Jun 26 & 0 & 3 & 0 & 2 \\
\hline 28 & 0 & 5 & 0 & 7 \\
\hline 30 & 0 & 2 & 0 & 0 \\
\hline $\begin{array}{ll}\text { Jul. } 2 \\
\end{array}$ & 0 & 2 & 0 & 14 \\
\hline 4 & 0 & 5 & 0 & 25 \\
\hline 6 & 0 & 13 & 0 & 22 \\
\hline 8 & 0 & 5 & 0 & 9 \\
\hline 10 & 0 & 2 & 0 & 11 \\
\hline 12 & 0 & 4 & 0 & 6 \\
\hline 14 & 0 & 3 & 0 & 16 \\
\hline 16 & 0 & 3 & 0 & 9 \\
\hline 18 & 0 & 19 & 0 & 6 \\
\hline \multicolumn{5}{|c|}{ Rice field } \\
\hline Aug. 8 & 0 & 3 & 2 & 22 \\
\hline 15 & 8 & 5 & 7 & 5 \\
\hline 22 & 6 & 14 & 19 & 9 \\
\hline 29 & 12 & 10 & 27 & 4 \\
\hline Sept. 5 & 19 & 30 & 37 & 12 \\
\hline 12 & 30 & 12 & 22 & 7 \\
\hline 19 & 21 & 22 & 16 & 5 \\
\hline 26 & 27 & 8 & 41 & 4 \\
\hline Oct . 1 & 10 & 7 & 23 & 5 \\
\hline 7 & 4 & 3 & 10 & 0 \\
\hline 14 & 0 & 0 & 0 & 0 \\
\hline Total & 137 & 172 & 204 & 200 \\
\hline
\end{tabular}

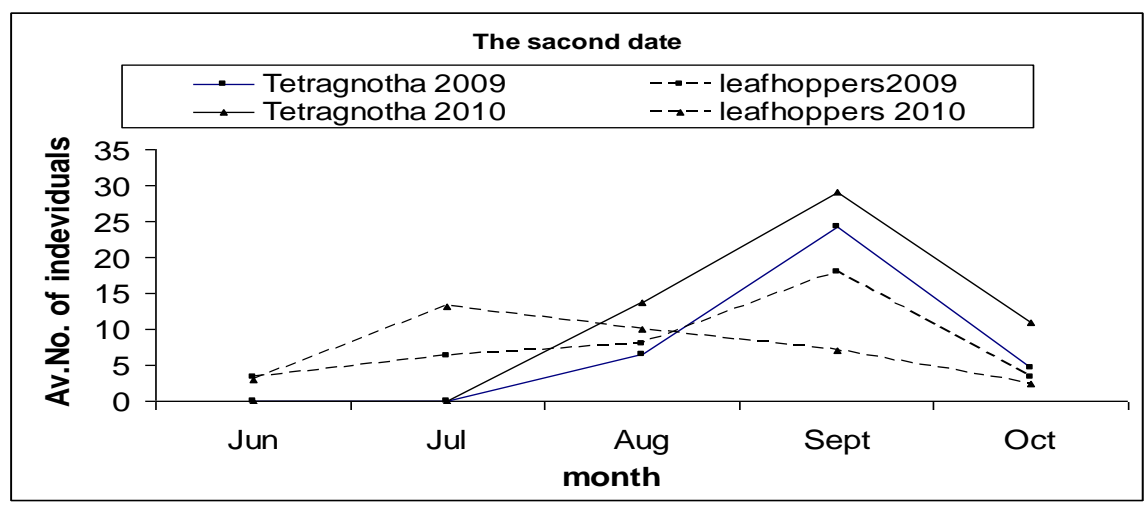

Fig (2):Population fluctuations of family Tetragnotha spp and rice leafhopper, per/ $\mathbf{5 0}$ double strokes in rice fields in sacand date. 
Acknowledgement; The author is deeply gratitude to. Prof. Dr. M.R. Sherif, Head of Entomology Department at Rice Research and Training Center, Sakha, Kafr El-Sheikh, Egypt for keen interest in reviewing the manuscript .

\section{REFERENCES}

Assas, M.S. and H. Boraei (2005). Spiders in kafr El- sheikh rice fields .J.Agric .Res. Tanta.Univ. Egypt., 31 (4-B).

Chiverton, P.A.(1986). Predator density manipulation and its effects on population Rhopalosiphum padi(Homo.:Aphididae) in spring barley. Ann. Appl. Biol., 109: 49-60.

Clark, M.S., J.M. Luna, N.D. Stone and R.R. Youngman. 1994. Generalist predator consumption of armyworm (Lepidoptera: Noctuidae) and effect of predator removal on damage in no-till corn. Environ. Entomol., 23:617-622.

Francis, A.D. and A. Randy . (2003) . Spider predation in Agroecosystems: can spiders effectively control pest populations .Technical Bulletion $190.1070-1524$.

Greenstone , M.H. (1999). Spider predation: how and why we study it. J.Arachnol.27: 333-342.

Nentwig, W. (1987). The prey of spiders. pp.249-263. In Ecophysiology of spiders (W. Nentwig,ed). Springer-Verlag, Berlin.

Riechert, S.E.and K. Lawrence. (1997). Test for predation effects of single versus multiple species of generalist predators: Spiders and their insect prey. Entomol. Exp. Appl., 84: 147-155.

Riechert, S.E.and K. Lawrence. 1997. Test for predation effects of single versus multiple species of generalist predators:Spiders and their insect prey. Entomol. Exp. Appl., 84: 147-155.

Sherif, M.R., A.S. Hendawy and M.M. El-Habashy. (2001). Spiders occurring in the Egyptian rice fields and adverse effect of insecticides. J Agric. Res. Tanta Univ., 27(3): 463-470.

Sunderland, K. (1999). Mechanisms underlying the effects of spiders on pest populations. The Journal of Arachnology, 27: 308-316.

Van den Bosch, R.,P.S. Messenger and A.P. Gutierrez. (1982). An introduction to biological control. Plenum Press, New York.

Wise, D.H.( 1993). Spiders in ecological webs.Cambridge University pres.

Young, O.P. and G.B. Edwards. (1990). Spiders in United States field crops and their potential effect on crop pests. J. Arachnol.,18:1-27. 


\section{Shawer, M.B. et al.}

العناكب الحقيقية في حقول الأرز المصرية بمنطقة رشيد ،محافظة البحيرة

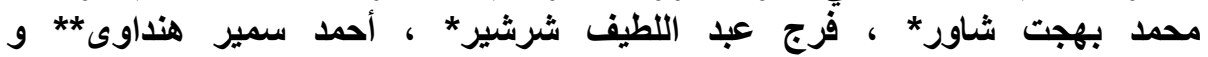

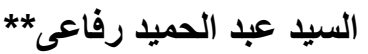

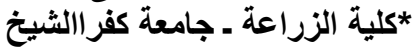
**معز بحوث وقاية النباتات ، محطة البحوث الزراعية ، سخا ، مصر

تم حصر عشرة أنواع من العناكب الحقيقية فى حقول الأرز المصرية بمحافظة البحيرة

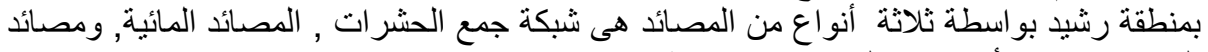

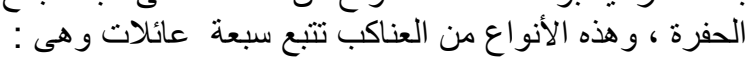

Thomisius sp.. Lycosa sp. Pardosa spp. Trochosa sp. Tetragnatha javana (Thorell), Tetragnatha nitens Thanatus albini, Singa sp. Dolomedes sp. and Mendoza sp .

وكانت أكثر المصائد جمعا هي شبكة جمع الحشرات (529-553 فرد) و أقلها هي مصيدة

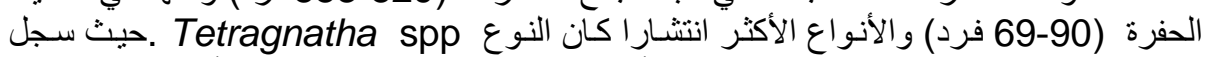

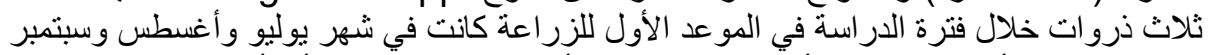

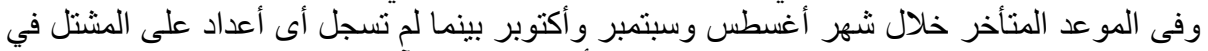

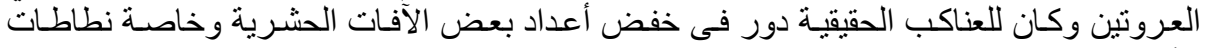

كلية الزراعة - جامعة المنصورة مركز البحوث الزراعية

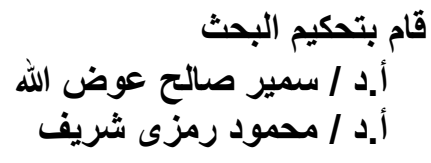

